Jnl of Ecclesiastical History, Vol. 73, No. 3, July 2022. (C) The Author(s), 2021 . Published by Cambridge University Press. This is an Open Access article, distributed under the terms of the Creative Commons Attribution-NonCommercial-NoDerivatives licence (http://creativecommons.org/licenses/by-nc-nd/4.o/), which permits non-commercial re-use, distribution, and reproduction in any medium, provided the original work is unaltered and is properly cited. The written permission of Cambridge University Press must be obtained for commercial re-use or in order to create a derivative work.

doi:10.1017/So02204692100066X

\title{
Remembering St Brictius: Conspiracy, Violence and Liturgical Time in the Danish Massacre of IOO2
}

\author{
by BENJAMIN SAVILL \\ Trinity College, Dublin \\ E-mail: benjamin.savill@tcd.ie
}

This article builds upon recent scholarship on the role of church 'reform' and the cult of saints in English royal politics around the turn of the second millennium, arguing that the infamous 'St Brice's Day massacre' of I 3 November IOO2 may have been planned for that date in part because of the associations of the cult of Brice/Brictius. After outlining this hypothesis, the article explores the broader implications of the emergence of a universal martyrological calendar for historical writing and political action, and for the exercise and communication of violence in particular.

As we follow the course of history, we recall - intermingled and fused together - as much the uirtutes of the saints as we do the massacres of peoples. For I do not think it should seem irrational if we commemorate the happy Lives of the blessed amid the slaughters of the wretched. Since that is how things have stood: it is not the indulgence of the writer, but the way of events. ${ }^{1}$

\footnotetext{
o began Gregory of Tours (d. 594) the second book of his Histories, $S$ introducing its first chapter, 'The episcopate of Brictius'. As Martin Heinzelmann demonstrated in his landmark study, Gregory's

$\mathrm{CCCC}=$ Corpus Christi College, Cambridge; $\mathrm{MGH}=$ Monumenta Germaniae Historica: SS = Scriptores; SS rer. Meroving. $=$ Scriptores rerum Merovingicarum; SS rer. Germ. = Scriptores rerum Germanicarum in usum scholarum seperatim editi

1 'Prosequentes ordinem temporum, mixte confusequae tam uirtutes sanctorum quam strages gentium memoramus. Non enim rationabiliter accipi puto, se filicem beatorum uitam inter miserorum memoremus excidia, cum idem non facilitas scripturis, sed temporum series praestitit': Gregorii episcopi Turonensis libri historiarum X, ed. Bruno Krusch and Wilhelm Levison, MGH, SS rer. Meroving. i/1, editio altera, Hanover $195^{1}$, ii. praef., $3^{6 .}$
} 
pairing of his prefatory statement on the mixte confusequae elements of Christian history with a short Life of his distant predecessor as bishop of Tours, St Brictius (d. 443), reflected a careful authorial choice. ${ }^{2}$ The remembered career of Brictius - the holy, if far from perfect successor to the great St Martin - had not gone smoothly. In his preface, Gregory set out much of the framework for his second book by recounting the mala and miracula that had struck Israel in equal measure under its leaders, both 'just' and 'sacrilegious': 'let the reader remember what evils befell Jerusalem', even in the time of its holiest Prophets!3 Gregory then took this Augustinian vision of the tumultuous civitas permixta, the interweaving of sin and sanctity in the fallen temporal world, as the typology for his following chapters. In 'The episcopate of Brictius', Tours itself plays Jerusalem's role.4 After Martin's death, Gregory tells us, the city and its anointed leader stood divided. St Brictius, 'proud and vain', had discharged his clerical duties less than honourably in his youth, openly clashing with Martin, and receiving the bishopric only through his curse. Once he had succeeded his 'incomparable' forebear, suspicion and malice began to brew among the citizens of Tours, who formed a conspiracy and rose up against him. A contrite Brictius sought to purge himself publicly and confess his youthful sins. Obstinate and unmoved, the citizens unjustly deprived him of his see, drove him out of the city and compelled him to flee in penitential exile to Rome. After seven years - and the episcopates of not one, but two usurpers - Brictius at last returned, taking back the city and ruling it happily until his death. Gregory's story hardly adheres to the saintly conventions of hagiography, and one would suppose he did little for the prelate's future commemoration. Yet by the central Middle Ages, St Brictius' feast was celebrated not only at Tours but throughout the Latin Church on 13 November. If not a major saint, he had become, against all odds, a universal one-and perhaps with one of the more strikingly unconventional back-stories in the pantheon.

In modern Anglophone historiography, however, the saint's name has fallen back into a curious blend of obscurity and ill-repute. If remembered at all, Brictius, or Brice, has become virtually synonymous with the recorded mass execution of Danes that took place under the orders of King Æthelred 'the Unready' on his feast day in 1002, an event now known exclusively, in academic and popular literature alike, as simply 'the St Brice's Day massacre'.5

${ }^{2}$ Martin Heinzelmann, Gregory of Tours: history and society in the sixth century, trans. Christopher Carroll, Cambridge 2001, 132-4. On the preface and its vision of Christian history see also Walter Goffart, The narrators of barbarian history (A.D. $55^{\circ}-$ 8oo): Jordanes, Gregory of Tours, Bede, and Paul the Deacon, Princeton 1988, 172-4, and Helmut Reimitz, History, Frankish identity and the framing of western ethnicity, 550-850, Cambridge $2015,44^{-} 5^{\text {o. }}$

4 Ibid. ii/1, pp. 37-8; Heinzelmann, Gregory, 132.

5 The best account is now Levi Roach, Athelred the Unready, New Haven 2016, $187_{-}^{-}$ 200, building upon Simon Keynes, 'The massacre of St Brice's Day (13 November 
While the event only makes a fleeting appearance in the contemporary record, its disturbing reminiscence of some of the worst genocidal acts of modern times has helped establish its position as one of the more memorable episodes in the Anglo-Saxon master narrative. There, it continues to exercise a curious allure over successive generations of undergraduate essay-writers and their lecturers, whose own occasionally lurid interest follows a historiographical tradition going back almost a millennium, beginning with the Norman observers who sought to depict the event as one of the great, gory English national sins justifying the Conquest of $1066 .{ }^{6}$ The event is attested by three sets of broadly contemporary evidence, now all well-known, but which it will prove helpful for the reader to recall briefly here. Firstly, three manuscripts of the Anglo-Saxon chronicle include an entry for 1002, probably written up in its existing form around 1020 , stating that,

in this year the king ordered to be slain all the Danish men who were in England; this was done on the mass-day of Brictius, because the king was told that they wished treacherously to deprive him, and then all his witan, of life, and then possess this realm. 7

This terse statement is supported by a more evocative account in a diploma of King Æthelred for the monastery of St Frideswide's, Oxford, of 1004, relating how he sought to make restitutions to its church following the damage done in a recent violent incident:

for it will be most well-known to all living in this country, that a decree of mine went out, with the counsel of all my leading men and satraps, that every Dane who had appeared on this island-just as tares sprout amongst the wheat [cf. Matthew xiii. 25-30] - was to be killed by a most just judgement [or 'extermination'] ... Those Danes lingering in the aforesaid town, seeking to evade death, entered this shrine of Christ, smashing by force its doors and bolts, and determined to make there an

1002)', in Niels Lund (ed.), Beretning fra seksogtyvende tvarfaglige vikingesymposium, Aarhus 2007, 32-66, and Jonathan Wilcox, 'The Saint Brice's Day massacre and Archbishop Wulfstan', in Diane Wolfthal (ed.), Peace and negotiation: strategies for coexistence in the Middle Ages and renaisance, Turnhout 2003, 79-92. See also Ryan Lavelle, Aethelred II: king of the English, Stroud 2002, 99-102, and Ann Williams, Ethelred the Unready: the ill-counseled king, London 2003, $5^{2-4}$.

${ }^{6}$ Keynes, 'Massacre', $43^{-} 5^{6}$. The argument that William of Jumièges may have recounted this event as early as the $105^{\circ}$ (pp. 44-5) now needs re-evaluation in light of the later date (1063/9) proposed by Tom Licence: Edward the Confessor: last of the royal blood, New Haven 2020, 298-300.

7 'on pam geare se cyng het ofslean ealle pa Deniscen men pe on Angelcynne wæron; ðis wæs gedon on Britius mæssedæig, forðam pam cyninge wæs gecyd pæt hi woldan hine besyrwan æt his life 7 siððan ealle his witan 7 habban sippan pis rice': The Anglo-Saxon chronicle: a collaborative edition, ed. D. N. Dumville and S. Keynes, Cambridge $1983^{-}$, s.a. 1002 C, also DEF. On the date of this part of the Chronicle see Simon Keynes, 'The declining reputation of King Aethelred the Unready', in David Hill (ed.), Ethelred the Unready: papers from the millenary conference, Oxford 1978, 227-53. 
asylum from where they might fight back against the people of the town and suburbs. But when all the people in pursuit, driven by necessity, strove to eject them but were unable, they made a fire of its planks and burnt down this church as is evident - together with its ornaments and books. ${ }^{8}$

Lastly, there is the putative archaeological evidence: mass graves of adult, probably Scandinavian males, at Oxford and Ridgeway Hill, Dorset, which may or may not bear witness to the same killings. The plausibility of these connections has been well analysed elsewhere. Perhaps of primary interest is that the sites suggest the deliberate 'public spectacle' of large-group executions, followed by conspicuously unceremonious mass burials (in the case of Oxford, within what looks like a monumental Neolithic henge, perhaps with enduring pre-Christian associations, immediately north of the town).9

In recent years interpretations of the massacre have become more nuanced and sophisticated. This has come as part of a broader effort to reassess the long-maligned reign of King Fthelred (978-1016) and stress its complexity, ${ }^{10}$ together with a sharper recognition of the role of church reformers in contemporary public life, and the importance of sin, penance, purgation and 'apocalyptic thought' in its political discourse and action. ${ }^{11}$ A good case has been made for the massacre not targeting $a d$

8 'Omnibus enim in hac patria degentibus satis constat fore notissimum quoniam dum a me decretum cum consilio optimatum satrapum que meorum exiuit ut cuncti Dani, qui in hac insula uelut lollium inter tricitum pululando emerserant, iustissima examinacione [for exterminacione? exinanicione?] necarentur [...] ipsi qui in prefata urbe morabantur Dani, mortem euadere nitens, hoc Xpi sacrarium, fractis per uim ualuis ac pessulis, intrantes asilum sibi repugnaculum que contra urbanos suburbanos que inibi fieri decreuerunt, set cum populus omnis insequens, necessitate compulsus, eos eiicere niteretur nec ualeret, igne tabulis iniecto, hanc ecclesiam, ut liquet, cum ornamentis ac libris combusserunt': The cartulary of the monastery of St. Frideswide at Oxford, ed. Spencer Robert Wigram, Oxford 1895-6, i/2, pp. 2-3. The text only survives in copies of the later twelfth century onwards, but is essentially authentic: Electronic Sawyer, no. 9o9, <https://esawyer.lib.cam.ac.uk/charter/gog.html>.

9 Roach, Ethelred, 196-200. The key literature is Louise Loe, Angela Boyle, Helen Webb and David Score, 'Given to the ground': a Viking Age mass grave on Ridgeway Hill, Weymouth, Oxford 2014, and Sean Wallis, The Oxford henge and late Saxon massacre with medieval and later occupation at St John's College Oxford, Reading 2015 , esp. p. 234.

${ }^{10}$ See above all the work of Simon Keynes and Pauline Stafford. Roach summarises this turn: Athelred, 3-5. For more recent considerations see Catherine Cubitt, 'Reassessing the reign of King Æthelred the Unready', Anglo-Norman Studies xlii (2021), 1-28.

${ }^{11}$ For example, Roach, Athelred, and 'Penitential discourse in the diplomas of King Æthelred "the Unready", this Journal lxiv (2013), 268-76; Catherine Cubitt, "The politics of remorse: penance and royal piety in the reign of Æthelred the Unready', Historical Research lxxxv (2012), 179-92, and 'Apocalyptic and eschatological thought in England around the year 100o', Transactions of the Royal Historical Society sixth ser. $\mathrm{xxv}(2015), 27-5^{2}$; and James T. Palmer, The apocalypse in the early Middle Ages, Cambridge 2014, 208-14. A full-length study is forthcoming from Catherine Cubitt. 
litteram 'every Dane' or person of Scandinavian origin in the kingdom, but rather recently demobbed members of the invading viking armies, who had settled following a truce made earlier that year. ${ }^{12}$ These executions have in turn been reinterpreted as less (in the words of the most influential AngloSaxonist of the early twentieth century) an outburst of 'spasmodic violence', than a carefully planned act, plausibly drawn up and put into effect by the reform-minded prelates who sat on the king's witan, among them the famous homilist and legislator Wulfstan, newly appointed archbishop of York (1002-23; also bishop of Worcester, 1002-16; previously bishop of London, 996-1002). From this perspective, the massacre fits into the wider reformist programme, evident throughout Wulfstan's sermons and laws, to purge England of its 'uncleanness' and drive out its sins and impurities, for which God was already punishing the nation through the viking scourge, a project ever more pressing as Christ's millennium and the End of Time loomed. ${ }^{13}$ However darkly, a Church-sanctioned purge of the kingdom's most recent foreign settlers-and perceived conspirators-made some sense within this world of political thought.

Yet one element of the massacre that has remained almost unexplored amid this ecclesiastical turn in readings of Æthelred's reign is the role played, however passively, by St Brictius himself. An important if overlooked article by Julia Barrow from 2007 stands as the exception. ${ }^{14}$ Following a study of the historical Brictius and a survey of aspects of his posthumous reputation, Barrow made the original and illuminating observation that St Martin's Day (1 1 November) had traditionally marked the beginning of slaughter season in medieval Britain, a process probably carried out in the eleventh century by large swathes of the population bringing their animals into market towns, 'when all the necessary equipment for an act of genocide - ropes, animal pens, axes and kniveswould have been ready at hand'. ${ }^{15}$ Brictius' role in this interpretation, however, remains firmly in the negative: Martinmas would have proved an unseemly occasion for the butchering of humans rather than animals, due to the high status of the saint. Better then, argued Barrow, to postpone the executions to a more obscure feast day, namely that of his less esteemed successor Brictius two days later. ${ }^{16}$ By this reading, the significance of the 'St Brice's Day massacre' lay in its insignificance: that it was not the 'Martinmas Massacre'.

${ }^{12}$ Keynes, 'Massacre', 37-43.

13 Wilcox, 'Saint Brice's Day Massacre'; Roach, Ethelred, 186-251. 'Spasmodic violence': F. M. Stenton, Anglo-Saxon England, Oxford 1943, 369.

${ }^{14}$ Julia Barrow, 'Bishop Brictius - Saint Brice', in Lund, Beretning, 67-88. Its lack of citations in the recent literature is probably due to the limited availability of the conference proceedings within which it appeared. These are however now available online at $<$ http://www.vikingesymposium.dk/symposieberetninger.htm>.

${ }^{16}$ Ibid. 83-8. 
This article follows Barrow's lead in asking questions about the timing of the event and its relation to Brictius, but takes a different approach, seeking instead to return the saint and his cult to the spotlight, and make a case for their significance after all. It by no means undermines existing interpretations, but rather aims to develop them further by exploring the ways in which the cult of saints, in this case the cult of Brictius, might have helped frame an act of extraordinary, 'state'-sanctioned violence such as the massacre that still bears his name. In its first section, it will briefly outline the reasons why Brictius (by whom is meant the saintly construct accessible to eleventh-century Christians, not the forgotten historical figure with whom Barrow's article is initially concerned) may have seemed to contemporaries a particularly apt figure under whose auspices such a singular act as these one-day, nationwide executions could be orchestrated. Such a reading is ultimately, and openly, one of hypothesis: considering the paucity of our source material, it has to be. Yet the case will be made for why this interpretation matters - encouraging us to think more seriously about the interconnections between the cult of saints, liturgical time, political action and historical writing around the turn of the second millennium, and about the exercise and communication of violence in particular. Its implications go well beyond Anglo-Saxon England and the reign of Æthelred.

\section{The penitential saint: the special case of Brictius}

The evidence must first be acknowledged for the reasonably wide recognition of St Brictius in later Anglo-Saxon England, together with his own unique qualities as a cult figure. He was not an unknown. While it can almost go without saying that Brictius never became a major saint, the manuscript evidence demonstrates that he by no means languished in obscurity. His connection to Martin did not merely result in his overshadowing - paradoxically, it must have at the same time propelled him into a Europe-wide religious consciousness by virtue of association. Most important, despite his relatively minor rank, Brictius enjoyed a de facto 'universal' status through his position as the principal or only saint listed for 13 November in all surviving Anglo-Saxon calendars from the ninth century onward. In the case of several, his name appears in a majuscule script, indicating his feast day as one of the more important of the month, comparable to those of All Saints (1 November), Eustace (2), Martin (11), Cecilia (22), Clement (23) and Andrew (30). ${ }^{17}$ This echoes his status in Carolingian

\footnotetext{
${ }_{17}$ Rebecca Rushforth, Saints in English kalendars before A.D. I I oo, Woodbridge 20o8, table Ix. On the category of 'universal' sanctity see Catherine Cubitt, 'Universal and local saints in Anglo-Saxon England', in Alan Thacker and Richard Sharpe (eds), Local saints and local churches in the early medieval west, Oxford 2002, 423-54.
} 
and post-Carolingian calendars, ${ }^{18}$ as well as in the immensely influential ninth-century Martyrology of Usuard, now thought to have circulated relatively widely in late Anglo-Saxon England as a key liturgical volume. ${ }^{19}$ (By contrast, his absence from the Old English Martyrology and Ælfric's sanctorale, as important as they are to us, may signify comparatively little: current research no longer considers the former a strictly liturgical text, while the latter has a number of curious omissions, not least of northern French saints whose cults are by the later tenth century otherwise well attested.) ${ }^{20}$ Brictius also featured in a number of Anglo-Saxon litanies, ${ }^{21}$ while at least two surviving English liturgical manuscripts record prayers for the saint, including for the office (Proper) of his feast day, ${ }^{22}$ complementing a contemporary continental tradition. ${ }^{23}$ What little remaining evidence we have of Anglo-Saxon relic-lists and labels shows that he could be found in at least one early eleventh-century English reliquary. ${ }^{24}$ It is true that we know of no early medieval churches named after Brictius in England. ${ }^{25}$ But more recent work has overturned older understandings about the simplicity (and monotony) of English minster consecrations: Anglo-Saxon church complexes and their dedications could be polyfocal - that is, with principal churches usually only dedicated to the Apostles or Mary, but potentially with multiple altars and shrines for other (now unrecorded) saints ${ }^{26}$ - and we cannot rule out the existence of secondary dedications which now lie beyond recovery.

${ }^{18}$ For example, Die Karolingischer Reichskalendar und seine Überlieferung bis ins I2. Jahrhundert, ed. Arno Borst, MGH, Libri memoriales, ii, Hanover 2001, iii. 1491.

${ }^{19}$ PL cxxiv.689. The only surviving exemplar from the period is CCCC, MS 57 , fo. $87 \mathrm{v}$ (s. $\mathrm{x} / \mathrm{xi}$, Abingdon or Canterbury), but for its wider use and importance see Sarah Hamilton, 'Understanding the Church's past: Usuard's martyrology in tenth- and eleventh-century England', Medieval Worlds x (2019), 46-6o.

${ }^{20}$ The Old English Martyrology, ed. and trans. Christine Rauer, Cambridge 2013, 16-17; Hamilton, 'Understanding', 51-3, 55-7; Mechthild Gretsch, Alfric and the cult of saints in late Anglo-Saxon England, Cambridge 2006, 1-20.

${ }^{21}$ Michael Lapidge, Anglo-Saxon litanies of the saints, Woodbridge 1991, 134, 175, 189, 206, $221,228,291$.

${ }_{22}$ CCCC, Ms 291, fo. $540 v$ (s. $\mathrm{xi}^{3 / 4}$, Worcester); BL, Ms Cotton Vitellius A. xviii, fo. $141 \mathrm{v}$ (s. $\mathrm{xi}^{2}$, Wells?): both manuscripts are slightly later than the period concerned but this is usual of surviving Anglo-Saxon liturgical codices, which only pick up in numbers in the eleventh century; it does not mean that they do not reflect earlier liturgical practice.

${ }^{23}$ For example Bibliothéque nationale de France, Paris, ms Lat. 5339, fo. $31 \mathrm{r}-\mathrm{v}$ (s. $\mathrm{xi}^{\text {in }}$, Angers?).

${ }^{24}$ BL, Ms Stowe 944, fo. $5^{8 \mathrm{v}}$ (1031 w/additions, Winchester New Minster); on this genre see now Julia M. H. Smith, 'The remains of the saints: the evidence of early medieval relic collections', Early Medieval Europe xxviii (2020), 388-424.

${ }^{25}$ Barrow, 'Bishop Brictius', 83 .

${ }^{26}$ Helen Gittos, Liturgy, architecture, and sacred places in Anglo-Saxon England, Oxford 2013, 55-102; John Blair, The Church in Anglo-Saxon society, Oxford 2005, 199-202, and 'A saint for every minster? Local cults in Anglo-Saxon England', in Sharpe and Thacker, Local saints, $455^{-94}$. 
Crucially, Brictius had a Life, and it was read in England. Less than 700 words in length, it was eminently well-suited to liturgical lectio, as its inclusion in the late Anglo-Saxon 'Cotton-Corpus Legendary' and its lost exemplar demonstrates. This text was, in fact, a recontextualised duplicate of the same short chapter of Gregory of Tours' Histories with which this article began, 'The episcopate of Brictius', now repackaged as an anonymous, standalone Vita Brictii, and transmitted alongside St Martin's hagiographical dossier (the so-called Martinellus). ${ }^{27}$ Indeed, it appears that Gregory's Histories were known in later Anglo-Saxon England substantially through this Vita Brictii, which by itself-and it is important to make this cleargave no indication of its original author or context. History had become hagiography, and by extension liturgy. ${ }^{28}$

This newly anonymised Vita Brictii is, however, notable for its eccentricity and deviation from standard hagiographical tropes. This of course came about in part as a consequence of its genre-transitioning detachment from its original context, but tenth- and eleventh-century English audiences would not have recognised this. Consequently, in this re-situated text, Brictius becomes reconfigured as a deeply unconventional, even unique saint: a figure of peculiarity as well as universality. Following the course of the Vita's narrative outlined above, ${ }^{29}$ four characteristics stand out. These were all in any case unusual, but they may have had a special

27 Bibliotheca hagiographica latina antiquae et mediae aetatis, Brussels 1898-1901, no. 1452: in CCCC, MS 9, fos $15^{\text {or-1 }} 5^{1 \mathrm{r}}\left(\mathrm{s}^{2} \mathrm{xi}^{3 / 4}\right.$, Worcester: a copy of a lost continental manuscript in use in tenth-century England: see Michael Lapidge and Peter Jackson [eds], 'The contents of the Cotton-Corpus Legendary', in Paul E. Szarmach [ed.], Holy men and holy women: Old English prose saints' Lives and their contexts, Albany, NY 1996, 131-46); Biblioteca Apostolica Vaticana, ms Reg. lat. 489, fos 1 20v-122v (s. xi ${ }^{1}$ or earlier, Canterbury Christ Church). Hereford Cathedral Library, ms O. vi. 11 $\left(\mathrm{s} . \mathrm{xi}^{\mathrm{ex}}\right)$, fos $62_{-3}$, is post-Conquest, but may attest to an earlier tradition. See also E. Gordon Whatley, 'Acta Sanctorum', in Frederick M. Biggs and others (eds), Sources of Anglo-Saxon literary culture, I: Abbo of Fleury, Abbo of Saint-Germain-des-Prés, and Acta Sanctorum, Kalamazoo Mi, 2001, 22-486, s.v. 'Briccius'. For the Martinellus in England see Andre Mertens, The Old English Lives of St Martin of Tours: edition and study, Göttingen $2017,5^{1-2}, 64-74$. The Vita's anonymised repurposing as essentially a new, independent text is obscured by some reference works, which list it as simply an extract from Gregory's Histories.

${ }_{28}$ For the Histories in England see Michael Lapidge, The Anglo-Saxon library, Oxford 2006, 21 2, 259, 307, and now Helmut Gneuss and Michael Lapidge, Anglo-Saxon manuscripts: a bibliographical handlist of manuscripts and manuscript fragments written or owned in England up to I IOO, Toronto 2014, 913. On the fragmented tradition of the Histories, including the Vita Brictii, see Pascale Bourgain and Martin Heinzelmann, 'L'Euvre de Grégoire de Tours: la diffusion des manuscrits', in Nancy Gauthier and Henri Galinié (eds), Grégoire de Tours et l'espace gaulois: actes du congrès international, Tours, 3-5 nov. 1994, Tours 1997, 273-317 at pp. 273-94, and Helmut Reimitz, 'The early medieval editions of Gregory of Tours' Histories', in Alexander Callander Murray (ed.), A companion to Gregory of Tours, Leiden-Boston 2016, 519-66.

${ }^{29}$ Gregory, Libri historiarum ii/ 1, pp. 37-8. 
resonance in millennial England. Firstly, Brictius was known for his wayward youth. In no way did he correspond to the topos of the saintly child, acting as if an ideal bishop or confessor from his earliest days. Nor, however, did he subscribe to the model of a youthful Christian conversion. Instead, he is shown in his younger days as an active clergyman, yet apparently unsuited to the role; only singled-out by Martin as his successor as a sort of punishment for his insubordination; and superbus et uanus (if, nevertheless, castus) even after his election to the bishopric. By at least the later Middle Ages, Brictius' background as a dissolute youth, who learnt only much later to 'govern' himself and others, had become established as one of his defining characteristics. $3^{\circ}$ In any case, the Vita makes clear that his juvenile misdemeanours and continued bad behaviour upon ascending the episcopal throne had led to the troubles that his leadership faced in his later years.

Secondly, these youthful shortcomings were compounded by the legacy of the inconparabilis St Martin. The Vita relates that this was not only about Brictius falling short of his predecessor's exceptionally high standards as a church leader, but about the direct power of Martin's uirtus over his fate, in life as in death. Martin had miraculously overheard the young deacon Brictius slighting him one day, leading him to confront him and prophesy that he would 'suffer many misfortunes in (his) episcopate' ('in episcopatu multa adversa passurum'). When, decades later, the populus of Tours proceeded to accuse Brictius falsely of sexual misdeeds, he sought to purge himself by undertaking an ordeal of hot coals at Martin's tomb-miraculously he remained unharmed, but the citizens expelled him regardless. The degree to which the Vita preoccupies itself with the difficulties of Brictius' succession is unusual, as is the prominence it gives to Brictius' contrite, late-career reverence for his predecessor's saintly tomb as a place of purgation and self-legitimisation.

This uprising against the saint constitutes the third peculiarity of the Vita. It does not portray Brictius as a poor, virtuous Christian persecuted by the state authorities: rather, he is the all-powerful authority, and it is his own subjects who turn against him. Likewise, he does not go on to accept the fickle fortunes of the secular world and abandon it for quiet contemplation-he returns to take the city again after the death of his usurpers. Some of this has faint echoes in aspects of later Merovingian 'political' hagiography, such as in the Passion of

$3^{\circ}$ 'BRYCE is sayd of Breos, that is to say in Greke as mesure, and of scio, scis, that is, to know. And thus the exposicion of this name Brictius or Bryce is as moche to say as knowynge mesure. For atte begynnynge of his enfancye whan he was yonge, he was full of many sottyes and folyes, but he coude well after the mesure of hym self demaunde and counceylle, and governe wel other and excuse hym self by mesure': William Caxton's edition of Jacobus de Voragine, Legenda aurea sanctorum, London 1483 , fo. 309 . 
Praiectus, ${ }^{31}$ but even these (certainly more obscure and localised) accounts tend to invoke external interference, and depict the relationship between the contentious bishop and his flock more ambiguously. Indeed, while the Vita hardly goes to any great pains to portray Brictius in much of a positive light, it ultimately presents the populus as the party in the wrong, a 'mob' ('turba'), which 'rose up' ('surrexit') against its rightful leader, 'rebelling against him in a conspiracy' ('insurgunt contra eum in una conspiratione') and committing 'evil' ('malitia'). Their confrontation of Brictius leads to his single miracle (a newborn speaks and denies his paternity); their 'disbelief and denial' ('non credentibus sed contradicentibus') towards both this and St Martin's implied defence of his successor during the tomb-ordeal clearly draws the line of right and wrong: the conspiratio is not only against an elected ruler, but God's saints. Whatever his faults, Brictius is the victim of the injustice, conspiracy and unbelief of his subjects-and ultimately he prevails.

Lastly, the penance undertaken by this saint looks especially unusual. The conspiracy against Brictius arises in the thirty-third year of his rule (Christ's age, although the Vita does not seem to need to point out this parallel). The self-purgation of his ordeal with hot coals at Martin's tomb turns to a dramatic display of full penance once he is exiled from the city, fleeing to Rome 'crying and wailing' and seeking out the pope, confessing to him how he 'deserved to suffer' since he had 'sinned' against Martin. ${ }^{22} \mathrm{He}$ would return only after seven years spent there weeping ('deflens'). Just enough papal correspondence survives from this period to suggest that an authentic episode lay behind this story: the historical Brictius may have lodged a legal petition of some kind with Pope Zosimus (41718). 33 All that matters to us, however, is how the Vita related the story by the later sixth century, and how it was still understood by the eleventh. In both cases, the issue no longer appears as one of canonical appeal, but penitential pilgrimage, 34 and indeed the public penance of a troubled ruler, 35 seeking late in his reign to regain his hold on power by making

$3^{1}$ Passio Praiecti episcopi et martyris Arverni, ed. Bruno Krusch, MGH, SS rer. Meroving., v, Hanover-Leipzig 1910, 225-48.

32 'Denique Brictius Romanae urbis papam expetit, flens et eiulans atque dicens: "Merito haec patior, quia peccavi in sanctum Dei".'

33 Epistolae Arelatenses genuinae, ed. W. Gundlach, MGH, Epistolae iii, Berlin 1892, 6-9 (= Philipp Jaffé, Regesta pontificum Romanorum ab condita ecclesia ad annum post Christum natum MCXCVIII, 2nd edn, rev. W. Wattenbach, S. Loewenfeld, F. Kaltenbrunner and P. Ewald, Leipzig $1885^{-8}$, no. 331); Barrow, 'Bishop Brictius', $70-4$.

${ }^{34}$ In this respect the seven years is especially suggestive. On this and the further numerical symbolism of his career see Barrow, 'Bishop Brictius', 77.

35 On perceptions of the bishop as 'ruler' $c$. 1 ooo see Timothy Reuter, 'A Europe of bishops: the age of Wulfstan of York and Burchard of Worms', in Ludger Körntgen and Dominik Waßenhoven (eds), Patterns of episcopal power: bishops in tenth-and eleventh- 
restitution with God. Such penitential saints were rare. Of all the cult figures known to have generated wide interest in Anglo-Saxon England, only Mary of Egypt shared a comparably penitential status, and as a sexworker-turned-desert-hermit her case was rather different. Lent, Pentecost and Advent made space for penance in the liturgical year, but the saints played no clear role in this; penitential leaders could be found in the Old Testament or, as with the Emperor Theodosius, earlier Christian history, but they were not objects of veneration. Perhaps here more than anywhere, Brictius offered something unique.

All this must have had a special significance in the English kingdom of 1002, and within the political thought of Æthelred's reign as understood by recent revisionist scholarship. Some readers will have already noted the Brictian-Æthelredian parallels. It seems difficult to think that these would not have gone unnoticed by the learned, cult-preoccupied higher clergy pre-eminent among the king's witan. It is now well-established that the 99os saw a marked shift in English royal politics which we might broadly call a return to the religious 'reform' programme promoted by King Edgar (957/9-75). This was instigated in part by the change of religious counsellors around Æthelred, and spurred-on by millennial anxieties and growing political instability..$^{6}$ What looks like a renewed emphasis on the cult of saints constituted part of this programme, something which of course has great significance here, 37 but wider political activity also developed around three key discourses, against which the case of Brictius must have taken on a special resonance. Firstly, the sudden change of policy in the 99os was explicitly framed as such, and promulgated as an effective 'mid-career' restitution on Æthelred's part for what Simon Keynes has influentially labelled his 'period of youthful indiscretions'. In the king's own words in a diploma of Pentecost 993, the 'ignorance of my youth' ('meae iuuentutis ignorantia') had been at the root of the 'afflictions', 'perils' and 'misfortunes' that had beset the early years of his reign, during which both royal depredations on ecclesiastical privileges and (with a neat sense of causation) Scandinavian attacks had abounded..$^{8}$ Æthelred and his counsellors therefore publicly communicated his millennial political

century western Europe, Berlin 201 1, 17-38. Again, the issue of whether or not the historical Brictius had actually 'ruled' fifth-century Tours is not relevant here. The Vita anyway depicts the ciues as having no leaders other than their bishops, whom they elect and depose themselves.

$3^{6}$ For this and much of what follows see now principally Roach, Ethelred, $133-85$. Seminal is Simon Keynes, The diplomas of King Ethelred 'the Unready', 978-1016: a study in their use as historical evidence, Cambridge 1980, 154-231.

37 Alison Hudson, 'Æthelwold's circle, saints' cults, and monastic reform, c. $95^{6-}$ 10o6', unpubl. DPhil. diss. Oxford 2014, $15^{-24 .}$

$3^{8}$ Charters of Abingdon Abbey, ed. S. E. Kelly, Oxford 200o-1, ii, no. 124 (Electronic Sawyer, no. 876); Keynes, Diplomas, 176-86; Roach, Ethelred, 91-132. 
'reform' programme as a watershed moment in the king's own personal development, from delinquent, discord-engendering iuuentus to the maturity of his later years. The parallels to Brictius (and he alone among the saintly pantheon) are, at the very least, intriguing. There may even be something in the possibility that Ethelred had himself turned thirty-three in 1002:39 that is, the same year in the episcopate of Brictius in which he had effected his own Christ-like, 'mid-life' purgation.

Next, there came the issue of troubled succession and the fallen standards of a saintly golden age. Æthelred's diploma of 993 forcefully contrasted the 'youthful indiscretions' of the king with the idealised world lost with the passing of his tutor, St Æthelwold (bishop of Winchester, 963-84), the chief architect of the 'reform' programme in the reign of his father, whose own cult became formally instituted in the mid-99os..$^{\circ}$ As with the Vita's account of Martin and Brictius, the diploma articulated this not merely as a matter of contrast, but of causation. Yet at least Brictius only had one eminent predecessor to deal with: Æthelred also needed to reckon with the towering legacies of Edgar and, perhaps more troubling, his brother Edward 'the Martyr', whose factional murder in 978 had opened the way for his own premature succession. As part of this new commitment to 'reform' and the mending of past wrongs, Fthelred and his circle had actively promoted the cult of Edward in these same years: the first reports of miracles at his tomb conveniently began in the 990 , and 1001 saw the (no doubt highly choreographed) translation of his relics to Shaftesbury. ${ }^{4^{1}}$ There are few hagiographical parallels for this later-life, tombside veneration of saintly predecessors as a means of signalling the turningpoint from the delinquency of one's early rule, but the case of Brictius fits this perfectly.

Finally, it has now become more or less an orthodoxy that Æthelredian politics from the early 990 s went beyond merely the communication of regret and restitution, and moved into the loftier realm of explicitly public penance. Such 'penitential kingship' followed in the tradition of figures such as Louis the Pious $(814-40)$, had its parallels in the contemporary reign of Otto III $\left(983^{-1002}\right)$ and worked within a wider sin- and penance-centred political discourse found in the writings of Æthelred's circle. ${ }^{2}$ However, the lives of the saints offered few helpful exemplars for this. What has hitherto gone unnoticed is that Brictius stands out as a

39 Æthelred was born somewhere between 966 and 969, when he appears in a royal genealogy of that year: Roach, Ethelred, 2o. It strikes me as likely that the drawing-up of the genealogy suggests not only a terminus ante quem for his birth, but evidence of its recent occurrence.

$4^{\circ}$ Barbara Yorke (ed.), Bishop Athelwold: his career and influence, Woodbridge 1988.

$4^{1}$ Roach, Ethelred, $167-74$.

$4^{2}$ Idem, 'Penitential discourse'; Cubitt, 'Politics'; cf. Mayke de Jong, The penitential state: authority and atonement in the age of Louis the Pious, 814-840, Cambridge 2010, and Sarah Hamilton, The practice of penance, 900-1050, Woodbridge 2001, 174-82. 
rare exception: not merely as a symbol of penance, but of penitential leadership. 43

The political atmosphere of 1002 may well have channelled these Brictian-Æthelredian connections into something urgent and tangibleconspiratio was in the air. The Anglo-Saxon chronicle asserts that a perceived conspiracy to overthrow Æthelred lay behind the massacre: 'the king was told that they [the targeted Danes] wished treacherously to deprive him, and then all his witan, of life, and then possess this realm'. We have seen that these particular 'Danes who had appeared on this island' (in the words of the Oxford diploma) probably comprised a defined group that had now settled within Æthelred's kingdom, perhaps in his service as mercenaries. Whether any conspiracy truly existed (and whether these Danes really had in some way become implicated in it) does not concern us here. What matters is that by the autumn of 1002 the court's sense of paranoia may have become highly charged: conspiracy could well have felt real. The increased intensity of Scandinavian raids from 997 onwards seems to have done much to rattle aristocratic confidence. The death of the dowager queen-mother Elfthryth in 1000/1001, and the death or disposal of Æthelred's first wife around the same time may have rocked the security of numerous court factions. We know that men once loyal to the king had suddenly deserted him, such as Pallig, a Dane, in 1001 , or had found themselves disgraced and forced into exile, as did Ealdorman Leofsige, who in early 1002 had reportedly murdered a royal steward. The coming 'Palace Revolution' of 1005 points to deep anxieties and erosions of trust around the king.44 Further afield, conspiracy, faction and rebellion weighed heavily in current affairs. In January 1002 Otto III had in some sense died an exile, fleeing, together with Pope Silvester II, from an uprising within their 'own' city of Rome; within that same past decade the last of the Carolingians had vanished in prison, following a botched coup against the new Capetian regime. 45 Notoriously, Æthelred himself had only come

43 See $n .35$ above. It is worth adding that the Vita's episode involving a penitential pilgrimage to papal Rome may have also been of special interest in millennial England - this same decade provides a unique (for the early Middle Ages) concentration of evidence for penitents heading to the city, through a series of documents involving the popes and Æthelred's archbishops Wulfstan and Ælfric: Robin Ann Aronstam, 'Penitential pilgrimage to Rome in the early Middle Ages', Archivum Historiae Pontificiae xiii (1975), 65-83; Harald Zimmermann, Regesta Imperii, II/5: Papstregesten, 9I I-IO24, 2nd edn, Vienna-Cologne-Weimar 1998, nos 799a, 983a, 983b, 983c; Karl Augustin Frech, Regesta Imperii, III/5: Papstregesten, I024-I058, Vienna-Cologne-Weimar, 2006-11, no. 24.

44 Pauline Stafford, Queen Emma and Queen Edith: queenship and women's power in eleventh-century England, Oxford 1997, 216-20; Roach, Ethelred, 186-7, 200-16; Licence, Edward the Confessor, 17-23; Cubitt, 'Reassessing', 7-8, 18, 27.

45 Gerd Althoff, Otto III., Darmstadt 1996, 169-89. The date of Charles of Lotharingia's death is uncertain, but may have been within a year of his capture and 
to power through an act of regicide. These were days of sedition, of toppled kings. Most pressingly, 1002 presented England with new dynastic complications and threats to the status quo, since in the spring of that year Æthelred took a new queen in Emma of Normandy, potentially risking the political alienation of his existing sons and their allies - a locus classicus of medieval rebellion. $4^{6}$ If the anxious prelates of Æthelred's witan turned to their calendars and martyrologies in autumn 1002 to find a propitious day for dispatching the suspected conspirators, 47 the messedeig of the sole saint who was the ruler-victim of an unjust political conspiratio, and who in the end triumphed over the malitia of those who would unseat him, must have had something to recommend it. Indeed, there is evidence to suggest that associations had been made between early medieval rulers troubled by revolt and the cult of Brictius before. The development of the site of Saint-Brice de Tournai at the tomb of the Merovingian patriarch Childeric I (d. c. 48o) has been linked, if only very tentatively, to that king's own reputation as a political rebounder, who had escaped an assassination plot by his subjects, then returned to seize power again. $4^{8}$ Much later, Odo of West Francia staged his second coronation at Rheims on St Brictius' Day 888.49 That ceremony followed a hotly contested first ten months on the throne spent facing down would-be claimants and their supporters, and was performed by a presumably humbled Archbishop Fulk, the (temporarily reconciled) ringleader of the most significant opposing

imprisonment at Orléans in 991: Jean Dunbabin, 'West Francia: the kingdom', in Timothy Reuter (ed.), The new Cambridge medieval history, III: c. 90o-c. Io24, Cambridge 1999, 372-97 at p. 390. $\quad 4^{6}$ Stafford, Queen Emma, 209-20.

47 On the timing of the decision see Wilcox, 'Saint Brice's Day massacre', $85-6$, who suggests that it may have occurred during a meeting of the witan (1002, after July) recorded in Charters of Abingdon, ii, no. 131 (Electronic Sawyer, no. 902). This is Wulfstan's first appearance as archbishop.

$4^{8}$ Guy Halsall, Cemeteries and society in Merovingian Gaul: selected studies in history and archaeology, 1992-2009, Leiden 2010, 193 ("Whether there is anything more than a coincidence in this - whether there was some earlier association between Childeric and Brictius' cult, because of the similarities in their careers - is unknown, unknowable, and possibly unlikely, but worth pondering'); Gregory, Libri historiarum ii/ 11 at pp. 612. Halsall emphasises that the tradition that Childeric's reign or indeed burial were 'pagan' is by no means secure: Cemeteries, 1 73-4. Either way, Childeric was not responsible for his posthumous memorialisation. There is no archaeological evidence for Saint-Brice predating the ninth or tenth century, although it is situated at an extramural, fifth-to-seventh-century Merovingian cemetery; the church was presumably associated in some way with Tournai's monastery of Saint-Martin, established by the Carolingian period: Raymond Brulet, M.-J. Ghenne-Dubois and Gérard Coulon, 'Le Quartier Saint-Brice de Tournai à l'époque mérovingienne', Revue du Nord lxviii (1986), 361-9; Laurent Verlype, 'La Topographie du haut moyen âge à Tournai: nouvel état des questions archéologiques', Revue du Nord lxxxi (1999), 143-62.

49 Annales Vedastini, in Annales Xantenses et Annales Vedastini, ed. B. de Simon, MGH, SS rer. Germ. xii, Hanover-Leipzig 1909, 40-82, s.a. 888. 
faction. $5^{\circ}$ As lay abbot of Saint-Martin de Tours, Odo surely orchestrated this re-inauguration date in full awareness of its symbolic message.

Ultimately this must remain a hypothesis. But there is a case, so let us be clear. In 1002 the king and his witan ordered the execution of a perceived ring of conspirators. They had supposedly sought to overthrow the king, who had orientated the past decade of rule as one of explicitly 'penitential kingship', articulated in particular around the perceived failings of his youth, and conducted under the shadow of his saintly predecessors Æthelwold and Edward the Martyr, whose own tomb-cults now saw heavy royal promotion, alongside, it seems, the cult of saints more broadly. The heavily 'reform'-minded witan, substantially composed of ecclesiastics (not least the newly elevated Archbishop Wulfstan), met to plan in advance the day on which the killings would take place. They chose a specific date: one dedicated to a universally recognised saint, who was, exceptionally, characterised as a penitential leader; as a renouncer of his youthful errors; as one who had long failed to live up to the model of his sainted predecessor, before turning to later-life, tomb-side veneration; and, quite uniquely, as the innocent target of a malicious political conspiracy, who with the aid of God and the saints, ultimately triumphed over his would-be usurpers. The simple assertion here is that this was not a coincidence. When the chronicler for 1002 explained that 'this was done on the mass-day of Brictius, because the king was told that they wished treacherously to deprive him, and then all his witan, of life, and then possess this realm', he may have sought to make this connection plain.

\section{Liturgical time, historical writing and political action}

At this point one might object that the witan (looking forwards) or the chronicler (looking back) had simply followed conventional terminology in dating the massacre to a saint's day. ${ }^{51}$ It should be recognised, however, that such 'conventions' had their own history and implications, which we cannot take for granted. Thinking of individual days primarily in terms of named saints seems to have developed relatively late into the early medieval period, and never became consistently applied. Conceiving of the shape of the year in such a way did not come valuefree, nor without consequences - dialectically, it both reflected a particular way of perceiving lived reality, and imposed meaning upon it. Important recent work has emphasised the need for historians to take seriously the 'liturgical framework of time' as a fundamental component in shaping

$5^{\circ}$ Geoffrey Koziol, The politics of memory and identity in Carolingian royal diplomas: the West Frankish kingdom (840-897), Turnhout 201 2, 81-5.

$5^{1}$ cf. 'the standard terms of the ecclesiastical calendar': Keynes, 'Massacre', 39. 
political activity, and in the perception of time and history of both writers and political actors. $5^{2}$ Scholars are now attuned to the idea that the 'onething-after-another' approach of Christian annalists and chroniclers reflects not their own imaginative deficiencies, but a theologically determined conception of the linear 'arrow of time' of universal history-the steady accumulation of the years as God's plan unveiled itself from Creation, to the Incarnation, and towards the Apocalypse.53 Yet as Christian history played out in real time along that linear, unidirectional pattern, it would also find itself relived, in a rotational rhythm within each year, according to two distinct liturgical cycles: what would become known as the temporale (the chronological cycle of the life, death and resurrection of Christ, culminating with Easter: a single narrative of salvation history) and the sanctorale (the achronological cycle of saint's feasts, usually allocated according to their days of death or burial: a vast series of discrete narrative episodes from earlier Christian history). 54 Contemporary events within the present were therefore continuously experienced through the lens of the lived cycle of collective remembrance of the Christian past, while the Christian past was in turn chiefly encountered through its day-by-day liturgical commemoration within the present. It is now well known that earlier medieval works on time typically preoccupied themselves with the Easter cycle/temporale, and that from at least the eighth century this became an important feature of historical writing (and presumably with it, to at least some degree, the lived experience of political life). What needs stressing here, however, is that annalists only began to pay attention to the sanctorale rather late in the day. We can probably attribute much of this to a lack of consensus across the post-Roman 'micro-Christendoms' as to which saint's days actually mattered, and exactly when one ought to have celebrated them. Any reader who has had to grapple with the horribly dense and textually unstable Martyrologium Hieronymianum of the seventh and eighth centuries, or tried to collate the diverse feast days allotted to the same saints in various sources prior to about 7oo, will sympathise with the monastic writers who deferred from using these feasts as ways of making sense of the past and present. 55

$5^{2}$ Margot Fassler, 'The liturgical framework of time and the representation of history', in Robert A. Maxwell, Representing history, 90o-1300: art, music, history, University Park, PA 2010, 149-72. See also Rosamond McKitterick, 'Liturgy and history in the early Middle Ages', in Katie Ann-Marie Bugyis, Margot E. Fassler and A. B. Kraebe (eds), Medieval cantors and their craft: music, liturgy and the shaping of history, Woodbridge 2017, 23-40.

53 Sarah Foot, 'Annals and chronicles in western Europe', in Sarah Foot and Chase F. Robinson (eds), The Oxford history of historical writing, II: 40O-I4OO, Oxford 2012 , $346-65$.

54 Fassler, 'Liturgical framework', $15^{8-9}$.

55 See, for example, the diversity of saints' feasts, $c .35^{\circ}-c .700$, registered on the University of Oxford's Cult of saints in late antiquity database, <http://csla.history.ox. ac.uk>; Martyrologium Hieronymianum, ed. Henri Quentin and Hippolyte Delehaye, 
By the ninth century, however, we can begin to see efforts towards a relative standardisation and, by implication, universalisation of a basic sanctorale. $5^{6}$ Carolingian and later Anglo-Saxon laws promoted the observance of important saints' feasts, 57 and normative texts from the eighth century to the time of the massacre urged clerics to carry with them a martyrological calendar or passionalis. $5^{8}$ By Æthelred's day these codices had become sufficiently hardwired into the ecclesiastical conception of time that his contemporary Thietmar of Merseburg (d. 1018) would dream of future events being revealed over their pages. 59

It makes sense, then, that it is only really from the ninth, and especially the later ninth and tenth centuries, that we begin to see Latin annalists bringing saints' days into their textual representation of the past and present. A full study of this development would prove richly rewarding, and there is only the space for a brief, preliminary survey here. By noting, however, the usually undervalued absence of such liturgical markers in western annals and chronicles up to the earlier ninth century, we can already get a better sense of what may have been a serious shift taking place in both historical writing and public life as the millennium progressed. ${ }^{60}$ Whereas the earlier Frankish annalists appear to have

Acta Sanctorum, Novembris ii/ 2, Brussels 1931. Felice Lifshitz's seventh-century date for the Hieronymianum is now generally accepted; the surviving manuscripts are eighthcentury: Oliver Nicholson (ed.), The Oxford dictionary of late antiquity, Oxford 2018, s.v. 'Martyrologium Hieronymianum'.

$5^{6}$ See the texts at nn. 17-19 above. One does not have to follow in full the thesis of Arno Borst that the Carolingians developed an 'official' calendar to agree that a broader move to uniformity was under way: Die karolingische Kalenderreform, Hanover 1998. For the ninth century as the crucial period in the development of the martyrological calendar see Jacques Dubois, Les Martyrologes du moyen âge latin, Turnhout 1978, esp. pp. 29-6o.

57 Concilia aevi Karolini, ed. Albert Werminghoff, MGH, Concilia ii, Hanover-Leipzig 19o6-8, ii. 269: 'De festivibus anni' (Council of Mainz, 813), subsequently widely circulated (including into England) via Collectio capitularium Ansegesi, ed. Gerhard Schmitz, MGH, Capitularia regum Francorum nova series i, Hanover 1996, ii/33, 555-6; Die Gesetze der Angelsachsen, ed. Felix Liebermann, Halle 1903-16, i. 78 (Af, 43), 240 (V Atr, 11-19), 252 (VI Atr, 17-25), 260-1 (VII Atr, 2, 7), 265 (VIII Atr, 9-12); Councils and synods, with other documents relating to the English Church, I: A.D. 87I-I204, ed. D. Whitelock, M. Brett and C. N. L. Brooke, Oxford 1981, i. 58-6o, 73-4.

$5^{8}$ Councils and ecclesiastical documents relating to Great Britain and Ireland, ed. Arthur West Haddan and Wiliam Stubbs, iii, Oxford 1871, 417; Councils and synods, i. 206-7.

59 Thietmari Merseburgensis episcopi chronicon, ed. Robert Holtzmann, MGH SS, rer. Germ. n.s. ix, Berlin 1935, vi. 47 at pp. $33^{2-5}$.

6o Such a shift is stressed by McKitterick, 'Liturgy', 23, although her focus is not on the sanctorale. A separate case may be presented by the 'Chronicle of Ireland', which is peculiar for its number of relatively early entries including saints' days: T. M. CharlesEdwards, The Chronicle of Ireland, Liverpool 2006, s.a. 756, 772, 799, 80o, 804, 833, 868; the 'Chronicle' may have been unusual for its exclusively clerical, rather than court, audience: ibid. i. 6 . Note however that the 'Chronicle' only survives through a 
found no cause to mention saints' feasts, ${ }^{61}$ and the Annales regni Francorum provide only such two references (St John the Baptist's Day, 8o1, and Martinmas, 828), ${ }^{62}$ we can observe in their late Carolingian continuators a significant departure in their more enthusiastic adoption of the martyrological calendar into their historical writing, and we see their 'long tenthcentury' successors taking this yet further-even if, and this is important to emphasise, such markers of time usually still did not appear as often as references to the Roman Calendar (for example VIII. Kal. Sept.) or the temporale. ${ }^{63}$ (Furthermore, the classicising, more strictly 'literary' historical works of that same period - for example those of Widukind, Liudprand, Richer or later Rudolf Glaber - did not refer to saints' days, suggesting a sensitivity to genre. ${ }^{64}$ ) We can observe a similar, if somewhat later shift

late, complex manuscript tradition, and that the nature of its composition is much contested. For an overview see Roy Flechner, 'The Chronicle of Ireland: then and now', Early Medieval Europe xxi (2013), 422-54.

${ }^{61}$ A single semi-exception is in the non-annalistic Fourth book of the chronicle of Fredegar: with its continuations, ed. and trans. J. M. Wallace-Hadrill, London 196o, 26, p. 17, where a challenge to a duel is recorded as falling on Martinmas 6o4. We know elsewhere of the contemporary invocation of Martin in Merovingian ordeals of royal justice, and so this timing was probably significant: cf. Die Urkunden der Merowinger, ed. Theo Kölzer, MGH Diplomata regum Francorum e stirpe Merovingica, Hanover 2001, i, no. 126.

62 Annales regni Francorum inde $a b$ a. 74 I usque ad $a .829$, ed. G. H. Pertz and F. Kurze, MGH, SS rer. Germ. vi, Hanover 1895, s.a. $801,828$.

63 Nithardi Historiarum libri III editio tertia, ed. G.H. Pertz and E. Müller, MGH, SS rer. Germ. xliv, Hanover-Leipzig 1907, ii. 10 (841); iv. 6 (843); Annales de Saint-Bertin, ed. Félix Grat, Jeanne Vielliard and Suzanne Clémencet, Paris 1964, s.a. 832, 833, 834, $895,837,838,839,862,865,869,870,874,876,877,878,879$; Annales Fuldensis sive annales regni Francorum orientalis, ed. G. H. Pertz and F. Kurze, MGH, SS rer. Germ. vii, Hanover 1891, s.a. 870, 884; Annales Vedastini, s.a. 881, 884, 888, 89o, 893, 898; Reginonis abbatis Prumensis chronicon cum continuatione Treverensi, ed. F. Kurze, MGH, SS rer. Germ. 1, Hanover 189o, s.a. 887, 894, 896, 918, 950, 964, 965, 966, 967; Les Annales de Flodoard, ed. P. Lauer, Paris 19o3, s.a. 921, 924, 931, 945, 962; Thietmari Merseburgensis episcopi chronicon i. 25 (c. 923), ii. 29 (972), iv. 16 (990), 21 (994), v. 13 (1002), 22 (1002), 44 (1004), vi. 9 (1004), 10 (1004), 13 (1004), 14 (1004), 27 (1005), 47 (1008), 58 (1010), 59 (1012), 66 (1012), 68 (1012), 69 (1012), 70 (1012), 74 (1012), 81 (1012), 84 (1012), 89 (1013), 96 (1013), vii. 24 (1015), 35 (1015-16), 51 (1017), 52 (1017), 66 (1017); Annales Quedlinburgensis, ed. Martina Giese, MGH, SS rer. Germ. lxxii, Hanover 2004, s.a. 993, 999, 1002, 1012, 1025; Annales Sangallenses maiores, ed. I. von Arx, MGH, SS, i, Hanover $1826,73-85$, s.a. 912, 913, 920, 952, 955, 964 (964), 989 (995), 1024 (1030), 1030 (1036), 1033 (1039); Annales Corbeiensis, ed. G. H. Pertz, MGH, SS, iii, Hanover 1838, s.a. 1019, 1026; Annales Hildesheimensis, ed. G. Waitz, MGH, SS rer. Germ. viii, Hanover 1878, s.a. 887, 993, 1002, $1035,1036,1037$.

${ }_{4}$ The single exception in Richer comes at the end of his autograph manuscript and may reflect an unfinished work-in-progress: Richeri historiarum libri III, ed. Harmut Hoffmann, MGH, SS xxxviii, Hanover 2000, iv.107, p. 306 (Staatsbibliothek Bamberg, Ms Hist. 5, fo. $55^{\mathrm{v}}$ ). Flodoard is especially instructive on this point, since his use of saints' days in his annals is absent from his Historia Remensis ecclesiae, ed. 
in the complex of writings that make up the Anglo-Saxon chronicle. There, events taking place on specific days are (with a single, perhaps retrospective exception) dated exclusively to the Roman Calendar or temporale until as late as the year 9oo, whereupon saints' feasts appear relatively regularly as ways of marking time, although they again by no means ever displace the older system. ${ }^{6} 5$ Such references might fall into three broad categories: (a) a straightforward record of the liturgical celebration of a saint's feast; (b) the dating of an event according to it falling upon, or near, such a day; or (c) a reflection of a particular event as having taken place because a certain saint's feast fell on that day. Once this convention had taken off in the ninth and tenth centuries, (b) appeared relatively frequently, as did (a) in works interested in royal itineraries (especially Thietmar's Chronicon, following the Emperor Henry II), although rarely explicitly in the Anglo-Saxon chronicle. Type (c) proves harder to identify, particularly since these annalists rarely spell out causation. Yet such thinking can be detected in Odo's coronation on St Brictius' Day (Annals of Saint-Vaast, s.a. 888). There are several further examples: the recording of Otto I's battle against the Magyars at Lechfeld on the feast of St Laurence, whose cult, and indeed holiday, had enjoyed vigorous promotion in the kingdom under his father (Annales Sangallenses maiores, s.a. $955) ; 66$ the co-ordination of the Breton uprising against the Normans on the feast of St Michael, the warrior angel who drove Satan from Paradise (Flodoard and, later, the annals of Sainte-Croix de Quimperlé, s.a. $931) ; 67$ and -in the eyes of the chronicler, more through heavenly than terrestrial agency - the intervention of the Virgin Mary in favour of the townsmen of London when they resisted Swein's army on the day of her Nativity (Anglo-Saxon chronicle, s.a. 994) ${ }^{68}$ Conversely, we might even find cases where annalistic silence is telling. The glaring failure of the Annals

Martina Stratmann, MGH, SS, xxxvi, Hanover 1998. On Flodoard's sense of genre see Foot, 'Annals', 349, and now Edward Roberts, Flodoard of Rheims and the writing of history in the tenth century, Cambridge 2019.

${ }_{5}$ Anglo-Saxon chronicle, s.a. 759 ABCDE (partly erased in F); $900 \mathrm{AB}, 901 \mathrm{C} ; 912 \mathrm{AB}$, ${ }_{913}$ CD; 914 B, 915 CD, 917 A; 918 A; 916 BCD (Mercian Register); 920 A; 933 A; 946 ABCD; 951 AF; 955 A; 963 A; 971 CB; 984 A; 994 CDE; 1002 CDEF; 1009 CDE; 1010 CDE; 1011 CDEF; 1014 CDEF; 1015 CDEF; 1016 CDEF; $1021 \mathrm{CDE}$; 1043 D; 1044 C, $1043 \mathrm{E} ; 105^{2} \mathrm{D}, 1048 \mathrm{E} ; 105^{2} \mathrm{C} ; 1053 \mathrm{D} ; 1054 \mathrm{D} ; 1060 \mathrm{D} ; 1065 \mathrm{CD}, 1064 \mathrm{E} ; 1066$ CDE.

${ }^{66}$ Annales Sangallenses, s.a. 955; Lorenz Weinrich, 'Laurentius-Verehrung in ottonischer Zeit', Jahrbuch für die Geschichte Mittel- und Ostdeutschlands xxi (1972), 45-66. See also Janet L. Nelson, 'Violence in the Carolingian world and the ritualization of ninth-century warfare', in Guy Halsall (ed.), Violence and society in the early medieval West, Woodbridge 1998, 90-107, and Michael Sierck, Festtag und Politik: Studien zur Tagewahl karolingischer Herrscher, Cologne 1995, 200-75.

67 Les Annales de Flodoard, s.a. 931; BL, Ms Egerton 2802, fo. 35.

68 Anglo-Saxon Chronicle, s.a. 994 CDE. 
of Saint-Bertin to note that Charles the Bald's defeat at the hands of his nephew at Andernach in 896 occurred on the vigil of St Denis, the emperor's personal patron, may reflect an effort to divert attention from the heavenly forces at work on a date which Charles had surely chosen deliberately for battle. ${ }^{69}$

However, these categories were in practice never discrete. Annalistic recording of events taking place in relation to saints' days such as the Purification of the Virgin (2 February) or Martinmas drew much of their significance from the ongoing development of the observation of these feasts as major fixtures of political life - in Francia, these were key dates for royal assemblies, themselves highly liturgised events with a significant ecclesiastical component. $7^{\circ}$ Clerical historians did not dryly impose saints' days over the course of political affairs, using them only as literary devices. From the ninth and tenth centuries they presumably mattered increasingly to annalists because they had already begun to have a serious bearing on the lived experience of the political year. $7^{71}$ Moreover, this relationship between political activity and the annals must have in any case proved reciprocal. Often it appears that these texts were composed with a public or court audience in mind: their textual representation of past events as taking place in relation to the martyrological calendar might have in turn influenced the timing and thereby framing of future political action. 'Court' and 'chronicler' often anyway overlapped. In this period we find well-known cases of annalists not merely tied to the court, but themselves protagonists of the decision-making, political elite. $7^{2}$ Nor, of course, did this cycle of saints' feasts in political life and its textual representation simply reflect a highly ritualised framework through

69 Annales de Saint-Bertin, s.a. 876; Nelson, 'Violence', 102-3. See also, for the argument that Regino deliberately juxtaposed the disorderly actions of his ill-fated, worldly protagonists against the backdrop of orderly, sacred time, Stuart Airlie, "'Sad stories on the death of kings": narrative patterns and structures of authority in Regino of Prüm's Chronicle, in Elizabeth M. Tyler and Ross Balzaretti (eds), Narrative and history in the early medieval west, Turnhout 2006, $105^{-31}$.

$7^{\circ}$ Sierck, Festtag, 276-322; Timothy Reuter, 'Assembly politics in western Europe from the eighth century to the twelfth', in Peter Linehan and Janet L. Nelson (eds), The medieval world, London 2001, 432-50 at pp. 434, 437-8. For the (typically, more limited) evidence of comparable activity in pre-Æthelredian England see Levi Roach, Kingship and consent in Anglo-Saxon England, 871-979: assemblies and the state in the early Middle Ages, Cambridge 2013, 71-6.

${ }^{71}$ Hans Martin Schaller, 'Der heilige Tag als Termin mittelalterlicher Staatsakte', Deutsches Archiv für Erforschung des Mittelalters xxx (1974), 1-24; Sierck, Festtag.

$7^{2}$ Foot notes the closeness of the ninth-century Annales regni Francorum and AngloSaxon Chronicle to the Carolingian and Alfredian courts respectively, and the especially notable case of Hincmar of Rheims composing the 861-82 sections of the Annales de Saint-Bertin: 'Annals', 357-6o. Comparably, later sections of Anglo-Saxon Chronicle D and $\mathrm{E}$ may have been composed under Archbishops Ealdred and Stigand: Licence, Edward the Confessor, 12-13, 254-62. 
which past and present was perceived. Besides all else, the intercession of a saint mattered - his or her invocation through their Proper of the Mass in each day's liturgy, in which the king and his circle might directly participate, bridged the link between mundane and heavenly agency in quotidian decisions and deeds. These feasts bore their uirtus. The fundamental point is that for writer, reader and actor alike, the raised prominence of an increasingly universalised martyrological calendar meant that each day came ever more loaded with the potential to be coloured by the memory, and even determined by the intercession, of the saint after whom it was universally named.

\section{Liturgical time and violence}

Such considerations may have weighed heavily on those planning the massacre of 1002. We must remember that the reason why this single event has attracted so much attention from historians of Anglo-Saxon England, from the post-Conquest era to our own, stems from its status as a truly exceptional act of co-ordinated, cold-blooded violence. It is partly because there are no suitable contemporary parallels for a premeditated, apparently country-wide, mass slaughter of unsuspecting members of a specific ethnic group, conducted outside any context of war or feud, that historians have tended to look instead to analogies with far more recent atrocities. The revulsion expressed by later Anglo-Norman writers shows that we cannot just lazily dismiss this as a typically 'medieval' episode, 73 even if, as suggested earlier, immediately contemporary interpretations may have proved more complicated. A foremost task for Ethelred and his witan was to limit what those interpretations could have been. Violence wasand is - a perspectival, contested and highly unstable category. Its exercise by those claiming legitimate authority requires its careful communication to observers as something which is in fact not 'violence' per se, but rather an act of force in the name of discipline or justice, in accordance with existing social and cultural norms.74 Late Anglo-Saxon England probably remained a bloody society that would look horrifically violent to us, but much of its brute force and bloodshed seems to have taken place within recognised 'public' arenas of royal justice, warfare or open feuding, wherein it earned its legitimacy. By contrast, a homicide became a

73 For these accounts see Keynes, 'Massacre', 43-55.

74 Fundamental is William Ian Miller, Humiliation and other essays on honor, social discomfort and violence, Ithaca, NY-London 1993, 7, 53-92. For this period see above all Halsall, Violence, and (although later in focus) and Hannah Skoda, Medieval violence: physical brutality in northern France, I270-1330, Oxford 2013. 
murder (and thus, 'violent', illegitimate) when committed in secret.75 Such an exceptional and seemingly unprecedented 'peacetime' act as the massacre of 1002 required very clear communication of its legitimacy indeed if it were not to become labelled then (as it was in the 1940s) as simply 'spasmodic violence'. Buttressing Æthelred's authority was one thing - so was keeping the wider peace. As with any aspect of early medieval law and order, the king depended on enforcement not through some sort of primitive Polizeistaat, but through embedded, co-operative elements within local communities: $7^{6}$ hence the pursuing 'people of the town and suburbs' described in the Oxford charter. The massacre required framing in such a way that it would not encourage and unleash further waves of bloodshed and disorder within society. Even with the limited contemporary evidence, we can clearly see that Æthelred and his circle had sought to communicate the massacre as a legitimate act of open, wellordered public justice. Once unleashed, it was publicised as sanctioned by the royal assembly (witan) in due retaliation to a plot already hatched. As a 'most just judgement' ('iustissima examinacione'), the order was not covered-up but made 'well-known' ('notissimum'). Its perpetrators pursued the victims purely since they were 'compelled by necessity' ('necessitate compulsus'), whereas it was the latter who had broken the peace when they 'smashed' into a church 'by force' ('fractis per uim'). 77 Their bodies were not hidden away but buried en masse in sight of alland not just anywhere, but in the deliberately un-Christian space of an out-of-town, ancient earthwork. Orderly staging, Inszenierung, meant everything.

Yet Inszenierung also required situating an act of violence within time, and finding it a place within future historical memory. Here, the prominence of universally recognised saints' days throughout the liturgical calendar raised potentially serious problems. Bloodshed was inevitably a year-round activity, but the notion that the feast days of at least some of the most important saints carried a strict taboo for the exercise of legitimate force had already begun to gain ground in the contemporary Peace movements sweeping through France. $7^{8}$ Worse still for the king and his advisors, the fact that the calendar of saints' days was populated predominantly (particularly among its 'headliners') by the ancient martyrs of the Roman Empire presented troubling limitations to the number of days on which one might co-

75 Tom Lambert, 'Theft, homicide and crime in late Anglo-Saxon law', Past E Present no. 214 (Feb. 2012), 3-43, and Law and order in Anglo-Saxon England, Oxford 2017.

$7^{6}$ Alice Taylor, 'Lex scripta and the problem of enforcement: Anglo-Saxon, Welsh, and Scottish law compared', in Fernanda Pirie and Judith Scheele (eds), Legalism: community and justice, Oxford 2014, 47-75; Lambert, Law, 152-6.

77 On this evident contemporary concern for public legitimacy see Wilcox, 'Saint Brice's Day massacre', 84-5: 'no sneaky business here'.

$7^{8}$ Geoffrey Koziol, The Peace of God, Amsterdam 2018, 53. 
ordinate such an exceptional and surely memorable act as the mass Danish killings of 1002. The point is obvious, but resists overstatement. The widespread recognition that any such day was dedicated to, let alone subject to the intercession of, one of the early saints who had famously been unjustly persecuted, hunted down and violently murdered by a tyrannical imperium and its hell-bound agents did not bode well for the communication of an act of exceptional, 'state'-sanctioned force such as that which Æthelred planned. Indeed, a recent study suggests that English religious sensitivity to the wider idea of martyrdom had become much more acute from the later tenth century.79 Simon Keynes has warned against level-headed scholars calling 13 November 1002 a 'massacre' on account of the word's dramatic evocation of such events in Christian history as, to use his own example, 'the Massacre of the Holy Innocents' ${ }^{80}$ Surely, however, this touches right at the point: the obvious connotations of the killings taking place on, say, Holy Innocents' Day (28 December), or any other feast of a persecuted martyr, would have made the communication of such brutality as a just and proper act nigh impossible. As the path-breaking work of Keynes and his school has shown, Ethelred and his witan were shrewd enough, and certainly liturgically minded enough, to have recognised this.

Might it then have simply proved easier to defer to a day entirely free of any widely recognised saints' feasts? Barrow is surely right to suggest that the association of Martinmas with butchery made the tools easily available, but held too much prestige to sully with homicide. But given that access to killing materials had probably never raised too many logistical difficulties in Anglo-Saxon England, could matters not have been arranged more flexibly? ${ }^{81}$ In fact, saints' days may have presented opportunities as well as obstacles for legitimising acts of force. A major problem for perpetrators and communicators of violence lay in its multivalence, and in an exceptional act of bloodshed that stood so far outside usual norms and practices as the massacre of 1002, the range of possible interpretations must have

79 Sarah Foot, Why were there no martyrs in the early English Church?, Cambridge 2020.

80 Keynes, 'Massacre', 32-3.

81 If we limit, probably unnecessarily, the window for possible action to the days around Martinmas, then the liturgical calendar was indeed tight, although one or two more 'neutral' occasions than St Brice's Day were arguably available. Across the twenty-three surviving pre-1066 calendars (Rushforth, Saints, table IX), 12 Nov. was always 'free', while on 10 November two calendars have entries for Justus, archbishop of Canterbury, one for Demetrius and one for Pope Leo (I); however, these dates would have been recognised as vigils of Martin and Brictius (although the implications of this would depend upon the degree to which either vigils were observed, that is, whether a full day or evening: if the latter, after dusk would prove inappropriate for 'legitimate' violence anyway). Only one calendar has an entry for 14 November (Theodocius), but in 1002 this fell on a Sunday. 16 November was however free of widely celebrated feasts, with five calendars having entries for Augustine (of Capua?, in one instance with his companion Felicity), and one entry for Ammonianus. 
been particularly wide, unstable and difficult to control. A generally recognised framework of liturgical time, however, offered a defined arena within which one might rein in these readings. The demarcation of a period of time as Britius messedaig had the power to impose meaning upon the events that took place within it, in the way the detached and austere Idus Novembris absolutely did not. Just as slaughtering one's enemies on Holy Innocents' Day might well prove a communications disaster, so might have the rebel Bretons, commencing their bloody uprising on Michaelmas, striven to convince waverers of the justness of their attempted expulsion. So too might have Charles the Bald, doing battle with his kinsman's army on the vigil of his patron saint, sought to reassure his men (and perhaps himself) of their legitimacy in an act of grim civil war. One must have trusted in saintly intercession as well. The argument here is that the same reasoning may well have applied to the timing of the massacre of 1002. This exceptionally cruel and unprecedented act needed careful communication and no doubt heavenly approval were it not to go down as a tyrannical outburst of 'spasmodic violence'. So: when better to time it, might have thought Æthelred's high priests and advisors, than to the single day on the calendar-one neither too sacrosanct nor too obscure - which was dedicated to, and under the intercessory aegis of, a penitential ruler? Who better a figurehead and patronus, than he who had made restitution for the troubles of his wayward youth; had cultivated and found the support of his sainted predecessor and mentor; and had suffered above all the unjust conspiracy and sedition of a column of malicious, unbelieving subjects, striving to deprive him of his rule - only for him to survive the ordeal and reassert his power triumphantly, with the favour of God and his elect? In Brictius, Ethelred's circle had found a unique saint for a unique and terrible event.

In time, of course, all efforts to communicate the mass killings of November 1002 as 'justice' rather than 'violence' failed, as their ultimate infamy testifies. Much of this depended on Norman and Anglo-Norman writers, who brought their own agendas. But we can already get a sense of matters spiralling out of control on the day, for we have seen how Æthelred found himself compelled, two years later, to make awkward public restitution to St Frideswide's, Oxford, for the perpetrators who had got carried away and razed its church. Indeed, one might be hard pressed to think of a more inauspicious case of a ritual gone wrong. Nevertheless, the classic age of moralising accounts of the 'St Brice's Day Massacre' arguably belongs to modernity, in the epoch of post-Reformation, national Protestant historical writing, when the event's notoriety became more securely established as part of the formation of the 'English historical tradition' ${ }^{82}$ We might well reflect, then, about

${ }^{82}$ Keynes, 'Massacre', 55-6. 
whether our own approaches in contemporary Anglo-Saxon (political) historiography to the relationship between time, political action and violence in this period might still remain a little too indebted to this confessionalised, Protestant legacy, one in which the calendar of the saints became in many respects 'drained of the sacred' 83 and increasingly reduced in the eyes of the historiographical mainstream to a mere catalogue of colourful names. This article has argued that the association of this event with 'St Brice's Day' was not, in its own time, a matter of empty labelling, but an intentional, meaningful act, infusing it with all the historical signification and numinous power that the real, living cult of saints made possible. By draining meaning from the calendar, one risks doing the same to the events which took place in dialogue with it. If we are to follow recent calls to pay more attention to 'the liturgical framework of time' in this period, we need to remain ever vigilant of the extraordinary potential the cultic calendar possessed to course through, colour and shape all political and social action in the minds of contemporaries, particularly in those cases where interpretations of events may have become more volatile, and more contested. Loca sanctorum existed in time as well as space, and there one could not bypass them so easily. We would do well to follow Gregory of Tours' admonition, with which we began: remembering that, 'in the course of history', the 'massacres of peoples' and 'slaughters of the wretched' would ever be 'intermingled and fused together' with the presence and perceived uirtus of the saints. The historian's task, as in Gregory's time, is to uncover those interconnections and entanglements, not artificially sift them apart according to specialism or taste. 'Since that is how things have stood: it is not the indulgence of the writer, but the way of events.'

83 Inverting the well-known formulation of $\mathrm{R}$. A. Markus, The end of ancient Christianity, Cambridge 1990, esp. pp. 125-35, 'The Christianisation of time'. 